\title{
AVALIAÇÃO DE DICIONÁRIOS: UMA PROPOSTA METODOLÓGICA
}

\author{
Enilde Faulstich*
}

\begin{abstract}
This text presents a methodological proposal to the evaluation of dictionaries of different types. We consider the evaluation procedures to be satisfactory enough in that dictionaries are richly informative reference works which require accurate reading. Having this in mind we made up a form with content details which usually are not met in dictionaries. To this end, we studied the macrostructure and the microstructure of some large dictionaries as the starting point to create guidelines in a record format. This study started at Lexterm Center in 1995 and continuous evaluations allowed us to improve it. Though not regarded as a definitive model, we recognized the proposal validity considering the number of works already analyzed;
\end{abstract}

Key-words: lexicography, dictionaries, Portuguese language, dictionary evaluation, glossaries, guidelines to evaluate dictionaries, macrostructure, microstructure.

\section{INTRODUÇÃO}

O Roteiro para avaliação de dicionários e glossários científicos e técnicos, elaborado por nós como resultado de um projeto desenvolvido no Centro de Estudos Lexicais e Terminológicos - Centro Lexterm da Universidade de Brasilia, teve uma versão publicada em julho de 1998, na obra denominada Cursos da Arrábida, Portugal, Terminologia: questões teórica, métodos e projectos ${ }^{1}$. À época, nosso interesse foi apresentar um método que possibilitasse a avaliação de dicionários de diferentes tipos e naturezas, de forma organizada e sistemática. No decorrer do tempo, o Roteiro foi validado, porque, vem sendo usado por estudiosos da lexicografia, que comprovam a utilidade do instrumento. Elaboramos o Roteiro para, justamente, oferecer um meio que possibilitasse sistematizar as informações contidas em uma obra lexicográfica ou terminográfica e, assim, fornecer ao leitor e ao usuário de dicionários uma síntese lexicográfica da vasta informação que um dicionário registra.

Neste artigo, apresentamos o Roteiro pela primeira vez minuciosamente descrito, de modo que todos os campos explicitados sejam entendidos na hora do preenchimento. Oferecemos, portanto, um texto metodológico com a explicação de cada campo, que não aparece na obra portuguesa de 1998. Reconhecemos a utilidade dessa publicação para que os avaliadores de dicionários sistematizem as informações, sabendo o que o lexicógrafo disse em cada um dos itens, no interior da obra.

Este artigo está organizado da seguinte maneira: I) apresentação do Roteiro vazio, sob a forma de ficha, com os itens que compõem a macroestrutura e a microestrutura de dicionários; II) explicação de cada um dos itens, que compõe os campos do Roteiro; III) apresentação, a título de ilustração, de Roteiros com os campos preenchidos, a fim de exemplificar como foram analisados alguns dicionários de diferentes épocas.

\footnotetext{
* Professora do Departamento de Linguística, Português e Línguas Clássicas (LIP), Instituto de Letras (IL), Universidade de Brasília (UnB). Coordenadora do Centro de Estudos Lexicais e Terminológico (Centro Lexterm/LIP/IL/UnB).

${ }^{1}$ Coordenação de Maria Helena Mateus e Margarita Correia, nº 04, Publicações Europa-América, 1998
} 


\section{ROTEIRO PARA AVALIAÇÃo DE DICIONÁRIOS DE LÍNGUA COMUM E DE DICIONÁRIOS OU GLOSSÁRIOS CIENTÍFICOS E TÉCNICOS}

Título:

Autor:

Editora:

Edição:

Data:

Local de publicação:

Volume(s):

Epígrafe:

\section{Sobre o autor}

1.1. Trata-se de pessoa reconhecida na área de dicionarística ou de terminologia?

1.2. Fez parte de grupo de pesquisa da área de dicionarística ou de terminologia?

1.3. Qual a formação acadêmica do autor principal e dos participantes do grupo de pesquisa?

1.4. Qual a profissão exercida na época da publicação da obra em análise?

\section{Sobre a apresentação da obra pelo autor}

2.1. Há introdução na qual apareçam claramente:

a) os objetivos da obra?

b) o público para o qual o conteúdo se dirige?

c) as informações sobre como consultar o dicionário ou vocabulário?

d) referências à bibliografia de onde foi extraído o corpus?

2.2. Há bibliografia de consulta justificada pelo autor?

\section{Sobre a apresentação material da obra}

3.1. Há prefácio redigido por personalidade reconhecida na área de dicionarística? Científica, técnica?

3.2. A família tipográfica empregada é adequada à faixa etária do usuário?

3.3. As ilustrações, se houver, estão adequadas à microestrutura informacional?

3.4. A utilização de negrito, de itálico e de outros recursos gráficos está de acordo com o equilíbrio visual da obra?

3.5. Os verbetes são apresentados em ordem alfabética? Em ordem sistemática?

3.6. A obra contempla uma só língua? Mais de uma?

3.7. O formato do dicionário ou vocabulário permite manuseio prático e fácil?

3.8. A obra está editada em suporte informatizado?

3.9. A qualidade do acabamento garante a sua durabilidade?

3.10. O sistema de abreviações e de símbolos aparece corretamente no corpo do texto?

3.11. A obra possui ampla divulgação?

\section{Sobre o conteúdo}

4.1. As entradas cobrem de maneira exaustiva a língua oral e escrita, inclusive neologismos, palavras derivadas, etc.?

4.2. Há entradas que se referem a áreas de especialidade?

4.3. Os verbetes apresentam:

a) categoria gramatical?

b) gênero? 
c) sinonímia?

d) variante(s) da entrada?

e) variante(s) da definição?

f) critérios para distinguir homonímia de polissemia? Quais?

g) marcas de uso? Como se classificam?

h) indicação de área ou subárea de especialidade?

i) contexto? ( exemplo ou abonação?)

j) equivalente(s)?

k) formação da palavra?

1) indicação de pronúncia?

$\mathrm{m})$ origem e etimologia?

n) divisão silábica?

o) nomenclatura científica?

p) remissivas úteis entre conceitos?

q) fontes?

r) notas?

4.4. A definição é constituída de um enunciado de uma só frase?

4.5. A definição leva em conta o nível de discurso do usuário?

\section{Sobre a edição e publicação}

5.1. Recomenda-se a edição e a publicação da obra?

5.2. Quais serão os principais pontos de difusão da obra?

\section{II - EXPLICAÇÃO DE CADA UM DOS ITENS QUE COMPÕEM OS DE CAMPOS DA FICHA}

\section{Informações gerais}

Título:

Autor:

Editora:

Edição:

Data:

Local de publicação:

Volume(s):

Epígrafe:

O conjunto "informações gerais" faz parte da macroestrutura de um dicionário. A macroestrutura é também chamada de paralexicografia, porque compõe o aparato de ordenação do texto. Os campos das informações gerais devem ser preenchidos com as informações ipsis litteris. Editora e gráfica são casas diferentes; a primeira é de ordem judicial, de conhecimento público e a gráfica é um estabelecimento em que se imprimem trabalhos. Às vezes, nos dicionários, aparece o campo Editora gráfica ou Gráfica editora, que, no caso de publicações, desempenha as duas funções. Nesse campo, devem ser registradas todas as edições e respectivas datas, anteriores à data da obra que está sendo analisada; essas informações são reveladas na apresentação ou na introdução do dicionário, a fim de que o leitor tenha a dimensão da quantidade de reprodução da mesma obra. No campo Volume, registramos cada uma das partes, encadernada separadamente, que compõe o todo de uma obra. A Epígrafe é um fragmento de texto que demonstra a motivação da obra, a quem se destina.

\section{Sobre o autor}

1.1.Trata-se de pessoa reconhecida na área de dicionarística ou de terminologia? 
1.2. Fez parte de grupo de pesquisa da área de dicionarística ou de terminologia?

1.3. Qual a formação acadêmica do autor principal e dos participantes do grupo de pesquisa?

1.4. Qual a profissão exercida na época da publicação da obra em análise?

O conjunto 1 situa o autor do dicionário no universo da lexicografia para que o usuário da obra conheça as condições de produção. No nosso Roteiro, as nomenclaturas "dicionarística" e "terminologia" referem, respectivamente, lexicografia de língua comum e lexicografia de linguagens de especialidade. Nessas áreas do conhecimento, o reconhecimento do autor está normalmente relacionado à publicação de obras anteriores ou de edições múltiplas, que põem em evidência sua atuação. Normalmente, as informações requeridas nos campos de 1.1 a 1.4. estão disponíveis, na paralexicografia, seja na apresentação, seja na introdução, seja no prefácio dos dicionários.

\section{Sobre a apresentação da obra pelo autor}

2.1. Há introdução na qual apareçam claramente:

a) os objetivos da obra?

b) o público para o qual o conteúdo se dirige?

c) as informações sobre como consultar o dicionário?

d) referências à bibliografia de onde foi extraído o corpus?

2.2. Há bibliografia de consulta justificada pelo autor?

Ainda no âmbito da paralexicografia, o campo 2 investiga a qualidade do texto que introduz a obra. Os objetivos de um dicionário demonstram a experiência do autor, se voltada para o interesse coletivo, se de cunho individual, assim como a isenção na formulação dos conceitos que aparecerão no corpo das definições. $\mathrm{O}$ público que receberá as informações regula o conteúdo descrito, que, por sua vez, precisa estar alinhado aos objetivos estabelecidos. A depender do público para quem a obra foi escrita, informações sobre como ler o verbete é um caminho com as pistas que servem para conduzir o leitor ao entendimento do texto lexicográfico. Se o dicionário tiver crianças como público alvo, as informações devem ser breves porque, também, o verbete é mais sucinto; se o público alvo for adulto, as pistas devem apresentar mais detalhes, em vista da extensão da informação e da compreensão do que foi dito para fins de uso imediato. As frases que abonam ou que exemplificam as palavras descritas constituem um corpus lexicográfico, extraído de obras escolhidas pelo autor para que o uso da palavra seja apreendida pelo leitor. A literatura da qual foram extraídas as abonações é um pressuposto para o tipo de público que vai receber a informação.

\section{Sobre a apresentação material da obra}

3.1. Há prefácio redigido por personalidade reconhecida na área de dicionarística? Científica, técnica?

3.2. A família tipográfica empregada é adequada à faixa etária do usuário?

3.3. As ilustrações, se houver, estão adequadas à microestrutura informacional?

3.4.A utilização de negrito, de itálico e de outros recursos gráficos está de acordo com o equilíbrio visual da obra?

3.5. Os verbetes são apresentados em ordem alfabética? Em ordem sistêmica?

3.6. A obra contempla uma só língua? Mais de uma?

3.7. O formato do dicionário permite manuseio prático e fácil?

3.8. A obra está editada em suporte informatizado?

3.9. A qualidade do acabamento garante a durabilidade da obra?

3.10. O sistema de abreviações e de símbolos aparece corretamente no corpo do texto? 3.11. A obra possui ampla divulgação?

O conjunto "apresentação material" possibilita uma visão sistemática da obra, acerca de aspectos pouco valorizados pelos consulentes, mas de grande importância para o conforto da leitura. No prefácio, além de o responsável fornecer informações sobre o conteúdo da obra, focaliza a pessoa e a produção do autor dicionário, a fim de relevar a importância da obra no estado da arte. Os tipos de letras usados na tipografia dos dicionários variam de acordo com a 
faixa etária do leitor. Normalmente, os tipos de letras usados nos textos dos dicionários infantis são maiores que os usados nos dicionários para adultos. Apesar de os dicionários não darem essa informação nos textos introdutórios, que antecedem a alfabetação lexicográfica, podemos inferir que, numa escala comparativa, por exemplo, o "Primeiro dicionário escolar de língua portuguesa", de Nelly Novaes Coelho (2005), usa carácter tipo 14 e o "Larousse Dicionário de Português" (2007), da série Minha $1^{\text {a }}$ biblioteca usa carácter tipo 12 pontos; ambos são dicionários para criança. Por outro lado, tanto o "Novo dicionário Aurélio da língua portuguesa" (2009), com a nova ortografia, quanto o "Dicionário Houaiss da língua portuguesa" (2009), com a nova ortografia, apresentam os verbetes com caracteres tipo 6. As letras tipográficas podem ser definidas por família (ou efeito): maiúsculas, minúsculas; por gênero (ou estilo da fonte): romano, normal, itálico, também chamado grifo, negrito, também chamado normando; por desenho (ou fonte): times new roman, garamond, calibri etc.; por corpo (ou tamanho): 6, 7, 8, 9, $10,11,12[\ldots]$ 72. A confecção gráfica dos dicionários resulta de muita pesquisa sobre tipo, carácter e fonte, pois, ao escolher a fonte, o serviço tipográfico leva em conta que cada tipo de corpo é medido em pontos e que isso leva a fontes diferentes. Assim, a aparente simplicidade de um dicionário para crianças opõe-se à frequente complexidade dos dicionários para maiores, por causa da quantidade de informação que um e outro contém. Assim, o tamanho da letra tende a ficar menor à medida que a idade do leitor aumenta.

As ilustrações, representadas por figuras, são um complemento para a compreensão da definição, principalmente de objetos concretos que não fazem parte de nosso dia a dia. Assim é que a ilustração de instrumentos musicais, de embarcações, de folhas das mais diferentes plantas tem importância prática. Por sua vez, é quase impossível ilustrar verbos e substantivos abstratos, sem que a figuração fique livre da idiossincrasia do ilustrador.

O uso de itálico ou de negrito depende de regras gráficas, com fins estilísticos, sob pena de o texto do dicionário produzir uma leitura cansativa e não-funcional.

Há uma diferença entre verbetes em ordem alfabética e em ordem sistemática. Os dicionários de língua comum têm por tradição a listagem em ordem alfabética; por sua vez, os dicionários terminológicos, os glossários, os vocabulários científicos e técnicos utilizam a apresentação dos verbetes em ordem sistêmica, porque os termos podem ser organizados por campos temáticos. Os termos, depois de organizados de forma sistêmica, podem ser dispostos em ordem alfabética no dicionário.

Os dicionários cujas informações aparecem em uma só língua são monolíngues. Alguns apresentam os equivalentes em línguas estrangeiras. E, por isso, são confundidos com dicionários bilíngues.

Dicionários que se abrem, totalmente, durante a consulta, são de fácil manuseio. Isso depende do tamanho do livro e da folha de papel, que, no processo de impressão, estão sempre em dependência. Como os dicionários são obras robustas por causa do formato bibliográfico, o manuseio é mais ou menos fácil, a depender das partes extratextuais, como capa, lombada e quantidade de páginas, entre outros.

Algumas informações, até então apresentadas, consideram mais a edição em formato de papel do que as edições informatizadas. Mas já é considerável a quantidade de dicionários produzidos por processo de digitalização, como CD-ROM, que tem a durabilidade vinculada à qualidade da produção. A diferença entre a edição em formato de papel e a informatizada é que esta última pode ter versões renovadas mais rapidamente, em função do avanço dos suportes eletrônicos.

É da prática lexicográfica o registro das abreviações e dos símbolos logo nas primeiras páginas dos dicionários. As abreviações e os símbolos, também chamados de reduções braquigráficas, são tipos de reduções indispensáveis em obras lexicográficas, porque reduzem e sistematizam informações repetidas, que não devem ser escritas por extenso a cada uso. Assim, economia e frequência caminham juntas.

Aceitação e divulgação se complementam, à medida que critérios diversos estão em jogo, entre outros, obra com número considerável de verbetes úteis e escritos de modo que o usuário entenda o que está sendo dito; exemplificação de usos da palavra, por meio de frases em que 
apareça a palavra no uso corrente e na data em que o autor escreveu o texto; valor histórico da obra; valor financeiro da obra.

\section{Sobre o conteúdo}

4.1. As entradas cobrem de maneira exaustiva a língua oral e escrita, inclusive neologismos, palavras derivadas, etc.?

4.2. Há entradas que recebem rubricas de áreas de especialidade?

4.3. Os verbetes apresentam:

a) categoria gramatical?

b) gênero?

c) sinonímia?

d) variante(s) da entrada?

e) variante(s) da definição?

f) critérios para distinguir homonímia de polissemia? Quais?

g) marcas de uso? Como se classificam?

h) indicação de área ou subárea de especialidade?

i) contexto? ( exemplo ou abonação?)

j) equivalente(s)?

k) formação da palavra?

1) indicação de pronúncia?

$\mathrm{m})$ origem e etimologia?

n) divisão silábica?

o) nomenclatura científica?

p) remissivas úteis entre conceitos?

q) fontes?

r) notas?

4.4. A definição é constituída de um enunciado de uma só frase?

4.5. A definição leva em conta o nível de discurso do usuário?

Este campo volta-se para a parte interna, para o miolo do dicionário. É necessário que o avaliador da obra esteja atento à época em que foi compilada ou elaborada. Para isso, é preciso distinguir etimologia de história das palavras. A distinção entre um método de análise e outro, grosso modo, consiste em que a etimologia busca o significado de uma palavra na origem, no caso do português, no latim; a história de uma palavra investiga, pelo confronto com outras línguas românicas e pelo estudo de textos, se a palavra tem sentidos concretos, se os significados variaram e se modificaram.

Um dicionário etimológico deve ser explicativo e as etimologias devem ser claras. $\mathrm{O}$ etimologista precisa ter vasta leitura de antigos documentos da língua e do baixo latim, conhecimento profundo de todas, ou das principais línguas românicas, que permita (re)composições verbais, além do conhecimento de línguas estrangeiras para que decida, na hora de escrever o verbete, se houve cruzamentos que possam influir na forma e no conteúdo da palavra; bom conhecimento de fonética portuguesa, espírito observador e perspicaz e talento especial para comparar e induzir com precisão e segurança, como informa Nascentes (1932, p. XIV)

Num dicionário histórico da língua, cada palavra aparece com as antigas formas e significações; se for palavra moderna, é preciso ter data de probabilidade da entrada na língua, pois a ausência dessa indicação representa um grande obstáculo para as investigações. Os métodos de trabalho, tanto para a pesquisa etimológica quanto para a histórica, são requintados e exigem procedimentos de ecdótica.

Entrada é, num dicionário, a unidade léxica, também chamada "cabeça do verbete" ou lema, que comanda todas as informações que compõem o verbete. Uma leitura no sentido vertical nas páginas da obra dá a informação se as palavras recolhidas para compor o dicionário são recolhidas de obras publicadas, portanto, da língua escrita ou se, também, o autor contempla 
expressões usadas na língua oral. Se foram incluídas palavras consideradas neológicas; se palavras derivadas ganharam destaque na obra, em vista de que a derivação é um processo fortuito no uso linguístico.

As rubricas de área de especialidade - ou marcas de uso - aparecem nos dicionários para indicar a categoria a que pertence a entrada, no universo do conhecimento. Esses registros são muito empregados em dicionários de língua comum, porque, nos terminológicos, a área já fica restringida pelo fato de serem de linguagem de especialidade.

$\mathrm{O}$ verbete constitui a microestrutura do dicionário, além de ser a parte, efetivamente, lexicográfica da obra, pois lexicografia é a disciplina que estuda, de forma analítica, as técnicas de elaboração de dicionários. Em cada unidade de verbete, o autor reúne as informações de gramática e de léxico que descrevem a entrada, de forma que o leitor tenha, naquela estrutura mínima, o máximo de informação. Entre as informações mais correntes, comentaremos as que seguem. A categoria gramatical é um dos critérios

para classificar partes do sistema lingüístico. O dicionário de língua comum contempla entradas com todas as classes de palavras registradas nas gramáticas tradicionais, e as abreviações correspondentes são listadas na parte paralexicográfica do dicionário. Por sua vez, os dicionários de linguagem de especialidade necessitam de um restrito número de classes de palavras, porque os termos que compõem as entradas são, em grande parte, nomes substantivos, algumas são verbos e outras, unidades terminológicas complexas (UTCs). A indicação de gênero ganha importância porque, na gramática do português, todos os nomes possuem gênero. Mais relevante, ainda, é a marcação de gênero em dicionários de linguagem de especialidade, porque um termo, fora de contexto, pode receber marcação de gênero masculino ou feminino, a depender do conceito e do significado que tenha no discurso.

É de conhecimento que o conceito de sinonímia apresenta controvérsia. Como o papel do avaliador de dicionário é verificar o que diz o autor da obra no texto lexicográfico, cabe, então, lançar no item se há ou não declaração de que existe registro de sinonímia no dicionário. Por sua vez, a sinonímia é um tipo de variação que produz variante. Mas o mais frequente é o autor lançar variante se houver duplicidade de grafia para um mesmo item lexical. É interessante observar que, em dicionários de linguagens de especialidade, a sinonímia é mais rara, em vista de que há uma tendência para que o termo de entrada seja "único". Essa verdade é relativa, porque uma língua, no uso quoditiano, pode apresentar mais de uma forma de escrever ou de dizer a mesma palavra que contenha o mesmo conceito. Ainda, nos dicionários de linguagem de especialidade, a variante da definição é uma estrutura textual que apresenta alguma diferença na forma de dizer o mesmo conceito. É preciso não confundir variante da definição com polissemia ou homonímia.

A polissemia é um fenômeno corriqueiro e frequente, que nos verbetes recebe numeração crescente quanto mais a definição se distancie do significado mais comum da entrada, por sentido figurado, ou por sentido emprestado de outras línguas ao português. Por isso, o lugar da polissemia é dentro do verbete, na definição, marcada antecipadamente por numeração crescente, como, 1. abcd... 2. efgh... 3. ijkl...

A homonímia se dá na forma da palavra, porque uma palavra, apesar de idêntica à outra, apresenta significados diferentes. Nos dicionários, os homônimos são geralmente marcados por números sobrescritos na entrada, como $\mathrm{xyz}^{1}, \mathrm{xyz}^{2}$ etc.

As marcas de uso ou rubricas situam as palavras na área de conhecimento em que são usadas com mais frequência. São antecedidas de abreviações que estão listadas no texto paralexicográfico do dicionário.

As áreas de especialidade são registros feitos por meio das marcas de uso ou rubricas. São muito usadas dentro dos verbetes e têm como função, além de marcar a especificidade da área, atenuar a polissemia, porque insere a palavra num contexto de especialidade, terminológico.

O contexto é a parte discursiva plena do dicionário, porque situa a entrada no uso efetivo da língua. Pode seguir uma redação criada pelo autor, a título de exemplo elucidativo, ou pode ser extraído de uma obra publicada, com o objetivo de abonar o uso feito por uma autoridade.

Os equivalentes de uma entrada aparecem quando o autor quer estabelecer uma relação entre 
línguas diferentes. No caso, entre a entrada e os equivalentes há operação mútua de significado, quer dizer, um significado numa língua de partida tem para esse mesmo significado uma palavra equivalente na língua de chegada.

Há dicionários que indicam a derivação ou a composição da entrada. Esse recurso atenua os cruzamentos linguísticos, ao demonstrar com que sufixo determinada base combina. É um recurso situado, por vezes, na formação da história da palavra ou da etimologia, porque uma base pode fornecer as condições semânticas para novas formações.

$\mathrm{Na}$ lexicografia em formato de papel, a indicação da pronúncia se dá por transcrição fonética, logo após a entrada, como um esforço de o autor conduzir o leitor ao uso oral da palavra. Algumas obras informatizadas apresentam o recurso de o consulente ouvir a pronúncia na língua de origem e em línguas estrangeiras que apresentam os equivalentes com a entrada na língua primeira.

Entre origem e etimologia há uma diferença no modo de apresentação da informação. A origem mostra a continuidade de uma palavra no tempo e no espaço; a etimologia procura demonstrar o étimo de uma palavra, quer dizer, a forma primeira que está na base da "criação" da palavra. Grosso modo, podemos dizer que a origem da palavra é de ordem morfológica, enquanto a etimologia é de ordem filológica. Esta remonta ao latim ou ao grego, ou a outra língua que forneceu caminho para chegar à língua sob análise. Neste caso, muitas palavras que entram no português, pelo inglês ou pelo francês, são marcadas no dicionário como 'do inglês (do ing.)' ou 'inglês (ing)', assim como 'do francês (do fr.)' ou 'francês (fr.)' ou ainda 'antropônimo (antr.)' sem que essa informação seja etimológica. São informações da origem da palavra, de onde provêm, e não de natureza etimológica, que procura dar conta do fundo léxico, entendido aqui como um componente no qual se acumulam todos os elementos léxicos de uma língua, assim como as regras por meio das quais é possível criar novos elementos de um modo produtivo. Uma informação etimológica remonta ao latim ( 'lat.'), ao árabe ('do árab.'), ao grego ('gr.), com o registro ora antecedido por preposição que indica ponto de partida (de+o), ora sem a preposição, alternância que nos dá a impressão de 'provir de' e de 'pertencer a'.

A divisão silábica é um recurso que praticamente não é usado nos dicionários, em vista da pouca utilidade na escrita, no entanto, quando aparece, serve para demonstrar que aquele grupo de força deve ser enunciado de uma só vez, ou para indicar, na translineação, que parte de uma palavra pode ficar separada da outra. Os dicionários que apresentam separação silábica são orientados para o ensino de segunda língua ou de língua estrangeira ${ }^{2}$ como benefício para os estudantes aprendizes da escrita.

Nomenclatura científica, dentro do verbete de um dicionário, corresponde ao que se chama nome científico da entrada. A nomenclatura serve para inserir os termos científicos em classes, de tal forma que do conjunto resulta uma classe nominativa em que todos os elementos pertencem à mesma categoria: Musa (bananeira); Musa acuminata (bananeira-anã); Musa coccínea (bananeira-vermelha); Musa arnoldiana (bananeira-de-jardim), entre outras.

As remissivas levam de uma informação à outra. Nos dicionários, o processo de remeter de uma informação à outra é remissão, e o resultado dessa remissão é uma remissiva. As remissivas, quando são empregadas nos dicionários, são marcadas, dentro dos verbetes, com $\mathbf{V}$. (ver ou veja) ou com Cf. (conferir). Ao agir dessa forma, o autor do dicionário serve de guia dentro da própria obra para abastecer o leitor de informação.

As fontes atestam de que documento escrito ou oral a palavra foi extraída. Pode ser um documento escrito original ou já de uso corrente, bem como um excerto de fala, que serve para demonstrar o emprego da palavra-entrada na língua ou o uso por comunidades. Dependendo da época em que o dicionário foi escrito e do tipo de dicionário, o registro da fonte com a data de entrada da palavra na língua se torna um fundamento histórico, um atestado de nascimento, como ocorre nos dicionários etimológicos.

As notas são raras nos verbetes dos dicionários de língua comum, no entanto são frequentes

\footnotetext{
${ }^{2}$ Cf. Oxford Advanced Learner's Dictionary; Señas Diccionario para la Enseñanza de la Lengua Española para Brasileños; Dicionário UNESP do Português Contemporâneo.
} 
nos dicionários terminológicos, porque explicitam informações que nem sempre são de conhecimento mais amplo.

A definição é, por regra, constituída de um enunciado de uma só frase. Se se considerar, do ponto de vista da estrutura, que uma frase é um enunciado que começa com uma letra maiúscula e termina num ponto, a definição pode ser, grosso modo vista, como tal. Do ponto de vista linguístico, a definição é um enunciado que expõe de forma sumária e clara as características genéricas e específicas, de um objeto, inserindo-o num determinado campo do conhecimento. Do ponto de vista lógico, a definição é uma equação que opera a igualdade entre a palavraentrada, que representa o objeto, e a predicação, que é o argumento, com vistas a atribuir as mesmas propriedades à palavra-entrada e à predicação.

Em vista do público-alvo, a definição deve ser elaborada de forma a permitir que o leitor para quem se dirige o dicionário compreenda o que está sendo dito pelo(s) autor(es). Nesses termos, é bom lembrar que a formulação de dicionários para crianças dá mais ênfase às ilustrações do objeto do que ao texto descritivo. Há, por conseguinte, uma certa inversão do signo saussuriano, no sentido de que o significante remete à referência concreta ( a imagem da coisa) e não a um significado construído (texto).

\title{
5. Sobre a edição e publicação
}

5.1. Recomenda-se a edição e a publicação da obra?

5.2. Quais serão os principais pontos de difusão da obra?

O campo 5 é de feição técnica. Quando estamos a serviço de uma editora, a informação tem poder de decisão; quando fazemos uma avaliação acadêmica, os itens do campo desempenham tem papel de sugestão.

III) APRESENTAÇÃO, A TÍTULO DE ILUSTRAÇ̃̃O, DE ROTEIROS COM OS CAMPOS DAS FICHAS PREENCHIDOS, COM BASE EM ALGUNS DICIONÁRIOS DE DIFERENTES ÉPOCAS.

\author{
Título: DICCIONÁRIO ETYMOLÓGICO, PROSÓDICO E ORTHOGRÁPHICO DA \\ LÍNGUA PORTUGUEZA ${ }^{3}$ \\ Autor: José Timóteo da Silva Bastos \\ Editora: Parceria Antonio Maria Pereira - Livraria Editora \\ Edição: $2^{\mathrm{a}}$ \\ Data: Anno de 1813 [com licença da Mesa de Desembargo do Paço] \\ Local de publicação: Lisboa \\ Volume(s): Tomo Primeiro A. - E. Segundo Tomo F. - Z. \\ Epígrafe: Offerecido ao Muito Alto, e Muito Poderoso Príncipe Regente N. Senhor
}

\section{Sobre o autor}

1.1 Trata-se de pessoa reconhecida na área de dicionarística ou de terminologia? Sim, foi um dos encarregados da $2^{\mathrm{a}}$ edição, 1925, Lisboa, do Dicionário de Caldas Aulete, como aparece no prefácio da $1^{\mathrm{a}}$ edição brasileira, de 1958.

1.2 Fez parte de grupo de pesquisa da área de dicionarística ou de terminologia? Não é mencionado.

1.3. Qual a formação acadêmica do autor principal e dos participantes do grupo de pesquisa? J.T. da Silva Bastos era diplomado em Letras e Sócio do Instituto de Coimbra.

1.4. Qual a profissão exercida na época da publicação da obra em análise? Não é mencionado.

\footnotetext{
${ }^{3}$ Roteiro preenchido por Cleide Lemes da Silva, pesquisadora do Centro Lexterm, doutoranda do Programa de Pós-Graduação em Linguística da UnB, na linha de pesquisa Léxico e Terminologia. Para os fins desta publicação, o original passou por pequenas adaptações.
} 


\section{Sobre a apresentação da obra pelo autor}

2.1. Há introdução na qual apareçam claramente:

a) os objetivos da obra? Não é mencionado.

b) o público para o qual o conteúdo se dirige? O autor afirma em seu antelóquio que "os consulentes são as pessoas do Brasil, onde se fala e escreve a língua portuguesa e onde se conserva ainda a antiga ortographia" e menciona ainda, "escriptores de Portugal e muitas pessoas de todas as classes".

c) as informações sobre como consultar o dicionário ou vocabulário? O autor chama de regras simples o que o consulente deve adotar para consultar o dicionário, como, por exemplo, o grupo ch, com o valor de $\mathrm{k}$ antes de e e i é substituído por qu, e assim escrever química (e não chimica). E lembra aos consultores "que lhes é conveniente, em caso de dúvidas ou de apparentes deficiências, recorrerem ao Supplemento d'esta $2^{\mathrm{a}}$ edição."

d) referências à bibliografia de onde foi extraído o corpus? Não é mencionado.

2.2. Há bibliografia de consulta justificada pelo autor? Não é mencionado.

\section{Sobre a apresentação material da obra}

3.1. Há prefácio redigido por personalidade reconhecida na área de dicionarística? Científica, técnica? O prefácio, como dito anteriormente, foi escrito pelo próprio autor.

3.2. A família tipográfica empregada é adequada à faixa etária do usuário? Como o autor diz que a obra será consultada por pessoas de todas as classes e de escritores tanto do Brasil quanto de Portugal, consideramos que a família tipográfica é adequada.

3.3 As ilustrações, se houver, estão adequadas à microestrutura informacional? Não apresenta. 3.4. A utilização de negrito, de itálico e de outros recursos gráficos está de acordo com o equilíbrio visual da obra? Sim. Ao iniciar cada letra da ordem alfabética, o dicionário apresenta a letra inicial no centro da folha, em fonte maior e em negrito. Todas as palavras - entradas são registradas em negrito, em fonte maior que a do verbete e recuadas $0,3 \mathrm{~cm}$ para dentro da coluna. Com relação à estruturação do verbete, o autor segue a uma padronização que dá um equilíbrio visual para a obra.

3.5. Os verbetes são apresentados em ordem alfabética? Em ordem sistemática? Os verbetes são apresentados em ordem alfabética. No "antelóquio", o autor declara que "se o consulente se decidir pela fórma official, não terá grandes dificuldades", pois determinadas palavras aparecerão, segundo o próprio autor, "quer se escreva á antiga quer á moderna, com ambas as grafias", como, por exemplo, em Telegráphico ou Telegráfico, que aparecem juntas como palavra entrada do mesmo verbete.

3.6. A obra contempla uma só língua? Mais de uma? O dicionário é somente de língua portuguesa. Embora apresente a origem das palavras em outras línguas, dirige-se aos falantes de língua portuguesa.

3.7. O formato do dicionário ou vocabulário permite manuseio prático e fácil? Sim. A obra está no formato impresso, é de tamanho médio, permite um manuseio prático.

3.8. A obra está editada em suporte informatizado? Não.

3.9. A qualidade do acabamento garante a sua durabilidade? A obra possui capa dura revestida de papelão, a encadernação foi feita de modo resistente, atributos que garantem a durabilidade da obra.

3.10. O sistema de abreviações e de símbolos aparece corretamente no corpo do texto? O autor apresenta apenas uma lista de sinais e abreviaturas, mas, ao consultar o dicionário, foram encontrados parênteses que designam, ao mesmo tempo: a área de especialidade; a chamada para a remissiva; uma espécie de nota; o neologismo; o nome científico do verbete; marcas de uso, entre outros. Há colchetes que apresentam a divisão silábica; a sílaba tônica; a pronúncia da palavra e, acreditamos que, para aproveitar totalmente os espaços vazios entre o término de um verbete e o início de outro, o autor faz uso dos colchetes para designar a continuidade de uma frase colocada no final do verbete, mas que se encontra quase que dando continuidade ao verbete que o antecede.

3.11. A obra possui ampla divulgação? Sim. 


\section{Sobre o conteúdo}

4.1. As entradas cobrem de maneira exaustiva a língua oral e escrita, inclusive neologismos, palavras derivadas, etc.? Em parte, sim. Foi encontrado o verbete Viviparação, classificado como neologismo e, vizconde como derivado de visconde.

4.2. Há entradas que se referem a áreas de especialidade? Sim, por exemplo, acapnia da medicina.

4.3. Os verbetes apresentam?

a) categoria gramatical? Sim. A categoria da palavra entrada aparece abreviada e em itálico.

b) gênero? Sim. Por meio de abreviatura em itálico, como por exemplo, $f$.

c) sinonímia? Não apresenta.

d) variante(s) da entrada? Sim. O autor coloca a palavra surubim como variante ortográfica de surubi.

e) variante(s) da definição? Não apresenta.

f) critérios para distinguir homonímia de polissemia? Quais? Embora o autor não mencione os critérios que adotou para distinguir homonímia de polissemia, vemos que o lexema Salva é considerado homonímico, uma vez que possui 4 entradas.

g) marcas de uso? Como se classificam? Sim. Por meio de abreviações e de acordo com a área de conhecimento, por exemplo, med. (medicina).

h) indicação de área ou subárea de especialidade? Sim.

i) contexto? (exemplo ou abonação?) Sim.

j) equivalente( $(s)$ ? Não apresenta.

k) formação da palavra? Não apresenta.

l) indicação de pronúncia? Sim, mas de algumas poucas palavras, como Vivo-t'o-dou [vivi-tu-dô].

m) origem e etimologia? Apresenta apenas a origem da palavra, por exemplo, Vitáceas (Do lat. Vitis).

n) divisão silábica? Não apresenta.

o) nomenclatura científica? Não apresenta.

p) remissivas úteis entre conceitos? Embora não apresente sequência de remissivas, o autor define a palavra entrada "Wolframite [vòl-fra-mi], s.f. (miner.) espécie de espinela" e nos remete à palavra entrada "Espinela s.f. mineral composto de alumina e uma base de zinco, ferro, etc."

q) fontes? Não mencionado.

r) notas? Sim, embora o autor não a classifique como nota, mas, pela forma como é descrita, entende-se como tal, como se observa em Afazeres s.m. pl. (orth. of. de affazeres) "Esta palavra tende a ser substituída pelo vocábulo mais correcto que-afazeres: Os seus quefazeres não lhe permittem distraçções". (BASTOS, 1813)

4.4. A definição é constituída de um enunciado de uma só frase? Em sua grande maioria, sim. 4.5. A definição leva em conta o nível de discurso do usuário? Como a obra é destinada às pessoas do Brasil, aos escritores de Portugal e muitas pessoas de todas as classes, sim.

\section{Sobre a edição e publicação}

5.1. Recomenda-se a edição e a publicação da obra? Sim. Desde que sejam integradas as palavras contidas no suplemento.

5.2. Quais serão os principais pontos de difusão da obra? Universidades, livrarias, escolas de ensino médio.

\section{Título: DICIONÁRIO UNESP DO PORTUGUÊS CONTEMPORÂNEO4}

\footnotetext{
${ }^{4}$ Roteiro preenchido por Margot Latt Marinho, quando, na condição de mestranda, cursou a disciplina Lexicografia e Terminologia,
} no Programa de Pós-Graduação em Linguística da UnB. Para os fins desta publicação, o original passou por pequenas adaptações. 
Autor: FRANCISCO S. BORBA (ORG.)

Editora: UNESP

Edição: $1^{\mathrm{a}}$

Data: 2004

Local de publicação: São Paulo

Volume(s): 1

Epígrafe: Ao CNPq, pelas bolsas de pesquisa que tornaram possível a realização deste trabalho.

\section{Sobre o autor}

1.1. Trata-se de pessoa reconhecida na área de dicionarística ou de terminologia? Francisco S. Borba é renomado na área de dicionarística; é autor de diversas publicações, incluindo o Dicionário gramatical de verbos do português contemporâneo do Brasil e o Dicionário de usos do português do Brasil, assim como os colaboradores são reconhecidos pesquisadores.

1.2. Fez parte de grupo de pesquisa da área de dicionarística ou de terminologia? O autor é membro da equipe do Laboratório de Lexicografia da Faculdade de Ciências e Letras - UNESP, Campos de Araraquara, sendo também de sua autoria o livro Organização de dicionários, uma introdução à lexicografia, ed. Unesp.

1.3. Qual a formação acadêmica do autor principal e dos participantes do grupo de pesquisa? A formação acadêmica não é mencionada. Entretanto, é sabido que o organizador da obra e os colaboradores são linguistas, professores e pesquisadores com notoriedade no meio acadêmico.

1.4. Qual a profissão exercida na época da publicação da obra em análise? Não é mencionado.

\section{Sobre a apresentação da obra pelo autor}

2.1. Há introdução na qual apareçam claramente:

a) os objetivos da obra? "Este dicionário dirige-se àqueles que se servem da língua escrita em algum momento da vida social e... como um ponto de apoio para professor em sala de aula." (BORBA, 2004, p. VII). Tais objetivos, segundo o autor, teriam orientado a organização da obra, estimulando "a pesquisa vocabular e a reflexão sobre o uso da língua, pela observação do jogo de contextos dentro de cada verbete.” Em Características Gerais, seção semelhante a um encarte no início do livro, afirma no item FEIÇÃO GERAL que "este dicionário procura registrar um espectro bastante abrangente das construções sintáticas (não desviantes, não tópicas) e da combinatória léxica da língua escrita no país a partir de 1950." (BORBA, 2004)

b) o público para o qual o conteúdo se dirige? A obra dirige-se aos consulentes em geral que se servem da língua portuguesa e, especificamente, a alunos do ensino médio e superior de qualquer área.

c) as informações sobre como consultar o dicionário ou vocabulário? As orientações para o consulente estão distribuídas da seguinte forma: seção Organização dos Verbetes em que estão identificados os elementos de estruturação dos verbetes (entrada, divisão silábica, classe e subclasse, variantes, estrangeirismos, pronúncia e outros) por legendas em nove exemplos extraídos da própria obra. As informações são claras e graficamente bem apresentadas; seção Símbolos e Abreviaturas em que estão listados símbolos e abreviaturas (nesta ordem) utilizadas na obras, com suas respectivas indicações; esses dados contribuem na identificação e compreensão das informações contidas nos verbetes; seção Símbolos Fonéticos em que orienta o consulente na pronúncia dos empréstimos listados no dicionário. Além disso, são fornecidos mais detalhes sobre: (i) critérios de seleção lexical e lematização das entradas; (ii) informações linguístico-gramaticais (gênero, transitividade dos verbos, adjetivos, regularidade e irregularidade na flexão, pronúncia, entre outros); e (iii) formulação das definições (linguagem, acepções, contextualizações entre outros). A concepção geral da obra, nos aspectos macro- e microestrutural, é apresentada no texto intitulado CARACTERÍSTICAS GERAIS. O conjunto de todas essas informações assegura ao consulente a sua independência no manuseio da obra.

d) referências à bibliografia de onde foi extraído o corpus? O dicionário é bastante claro nas informações quanto à seleção lexical: "Estabeleceu-se o conjunto das entradas pelo critério de ocorrência num corpus de cerca de 90 milhões de itens lexicais em textos escritos no Brasil, a 
partir de 1950". O material foi extraído do banco de dados do Laboratório de Lexicografia da Faculdade de Ciências e Letras de Araraquara - UNESP. Para selecionar de modo mais acurado um conjunto de entradas representativo do uso do português contemporâneo, levou-se em conta cada tipo de literatura que compõe o corpus de referência: romanesca, técnica, dramática. De modo geral, extraíram-se do corpus os itens que tiveram no mínimo duas ocorrências em textos diferentes. (BORBA, 2004, p. VII-VIII).

2.2. Há bibliografia de consulta justificada pelo autor? Sob o título Corpus, encontra-se um apêndice, elencando em ordem alfabética, as obras utilizadas exclusivamente para as abonações. O autor ainda informa que as questões gráficas seguem o VOLP - Vocabulário Ortográfico da Língua Portuguesa. Academia Brasileira de Letras. $3^{\mathrm{a}}$ ed. Rio de Janeiro, Corbã Editora Artes Gráficas Ltda, 1999.

\section{Sobre a apresentação material da obra}

3.1. Há prefácio redigido por personalidade reconhecida na área de dicionarística? Científica, técnica? A obra não contém prefácio.

3.2. A família tipográfica empregada é adequada à faixa etária do usuário? Não há dificuldade de leitura. Conforme as informações sobre o livro (última página, após a seção Corpus), o tipo gráfico empregado foi Times New Roman 8/8, 2. O tamanho da fonte, o espaçamento entre letras e linhas, e a impressão nítida, sem manchas ou falhas, são elementos que facilitam a leitura e tornam a consulta prazerosa.

3.3. As ilustrações, se houver, estão adequadas à microestrutura informacional? Há 283 ilustrações (dado registrado na capa de trás do livro) de tamanhos adequados, bem distribuídas, sempre ao lado dos verbetes correspondentes e com legenda. Não são meramente decorativas; trata-se de um recurso a mais na explicitação dos sentidos, como em: CÍMBALO, CÍTARA, CLEPSIDRA, MUNZUÁ, POLICHINELO. Observa-se, entretanto, que nos verbetes que possuem acepções diferentes, as legendas não fazem referência à respectiva acepção, como em COCHE co-che $(E s p)$ Sm 1 antiga carruagem fechada 2 carro ou carruagem fúnebre: Chegava o coche para levar o defunto. (a ilustração não faz referência à acepção correspondente).

Tais referências só ocorrem em homônimos homógrafos, por se encontrarem em entradas independentes e enumeradas. Neste caso, as ilustrações são acompanhadas de legendas também enumeradas. Exemplos: $\mathbf{C R A V O}_{1}, \mathbf{C R A V O}_{2}, \mathbf{C R A V O}_{\mathbf{3}}$ (a ilustração corresponde à entrada $\mathrm{CRAVO}_{3}$ ).

3.4. A utilização de negrito, de itálico e de outros recursos gráficos está de acordo com o equilíbrio visual da obra? A proposta visual é muito equilibrada. Todas as entradas recebem destaque em negrito e caixa alta. As abreviaturas que informam a classe gramatical são indicadas também em negrito. No caso de duas ou mais acepções, a distinção se faz por meio de numeração em negrito. Os colchetes indicam pronúncia, quando posicionados ao lado da divisão silábica; a divisão silábica recebe outro tipo de letra, em tamanho menor. Diferentes símbolos indicam: destaque, separação de blocos de informações, origem de palavras, equivalência de sentidos e demais informações pertinentes ao esclarecimento. Os exemplos são grifados em itálico e as legendas das ilustrações estão em negrito.

3.5. Os verbetes são apresentados em ordem alfabética? Em ordem sistemática? Os verbetes estão organizados em ordem alfabética. Todas as entradas estão em caixa alta, impossibilitando a distinção quanto ao emprego da maiúscula. As seções das letras $\mathrm{K}, \mathrm{W}$ e $\mathrm{Y}$ também são encontradas na obra, obedecendo ao critério de ordem alfabética.

3.6. A obra contempla uma só língua? Mais de uma? É um dicionário monolíngue do português contemporâneo. Entretanto, a nomenclatura abrange empréstimos de diversas línguas.

3.7. O formato do dicionário ou vocabulário permite manuseio prático e fácil? O tamanho é relativamente pequeno e a espessura adequada. O dicionário fica plano quando aberto, o que facilita a consulta, bastando uma das mãos para a leitura.

3.8. A obra está editada em suporte informatizado? A obra até o momento não está disponível em suporte informatizado.

3.9. A qualidade do acabamento garante a sua durabilidade? A encadernação é robusta. $\mathrm{O}$ 
revestimento do dicionário parece ser feito com cola de boa qualidade, levando-se a crer que será resistente a manuseio intenso. A capa é mole, mas foi confeccionada com papel cartão de boa gramatura (cartão supremo $300 \mathrm{~g} / \mathrm{m}^{2}$ ).

3.10. O sistema de abreviações e de símbolos aparece corretamente no corpo do texto? Sim. Os domínios discursivos, os registros de uso e as origens são informados logo após a classe gramatical, entre parênteses e grifado em itálico. As subclasses, logo após a divisão silábica e entre colchetes. Os símbolos também são empregados com correção.

3.11. A obra possui ampla divulgação? Sim. Está em todas as livrarias conceituadas da cidade e, também, divulgada pela internet.

\section{Sobre o conteúdo}

4.1. As entradas cobrem de maneira exaustiva a lingua oral e escrita, inclusive neologismos, palavras derivadas, etc.? A seleção lexical é bastante abrangente. Seguramente as palavras desconhecidas pelos consulentes serão encontradas na obra, mesmo porque não há lacunas significativas nas sequências, que possam comprometer a pesquisa. Foram constatados regionalismos, como "cabra da peste, carapanã", entre outros. Embora contemple a diversidade do território nacional, a maioria dos verbetes não apresenta indicação da região, como ocorre nos verbetes "pandorga", "papagaio", "pipa". Há registro de palavras compostas, como por exemplo, "mestre-sala", "doce de coco", entre outros. Encontram-se palavras derivadas, tais como: falível, doador, provedor. Existem vocábulos pouco usados e/ou em desuso (como "janota", "radiola", "memorandum"), empréstimos lexicais recentes (como "backup", "datashow") e empréstimos lexicais não recentes (como "blitz", "via crucis"). Os empréstimos não aportuguesados são grafados em itálico. A pronúncia desses empréstimos é indicada adequadamente por símbolos fonéticos, de acordo com a tabela na seção "Símbolos Fonéticos". Foram registrados neologismos (como "atachar", "deletar"), nomes próprios nas definições (como "machadiano", "socrático") e expressões idiomáticas, as quais são indicadas pelo símbolo ", a saber: "navegar contra a maré", "navegar em águas turvas", "de orelha", "de orelha em pé”.

4.2. Há entradas que se referem a áreas de especialidade? Elas configuram de modo completo a área à qual se referem? Sim. ABULIA a-bu-li-a Sf (Psic) falta de vontade: A campanha desenvolveu-se em completa abulia. ACONDROPLASIA a-con-dro-pla- si-a Sf (Med) doença congênita caracterizada por insuficiência no crescimento dos ossos longos, que, entretanto, se desenvolvem em espessura. ACONITINA a-co-ni-ti-na ( $F r)$ Sf (Quím) alcalóide cristalino branco, muito venenoso. A obra informa, na lista de abreviaturas, que foram abrangidas as seguintes especialidades: Aeronáutica, Álgebra, Anatomia, Antropologia, Arquitetura, Artes Gráficas, Artes Plásticas, Astrologia, Astronomia, Automobilismo, Basquete, Biologia, Bioquímica, Botânica, Cerâmica, Cinema, Citologia, Comunicação, Desportos, Direito, Ecologia, Economia, Eletricidade, Engenharia, Equitação, Estatística, Farmacologia, Filosofia, Finanças, Física, Fisiologia, Físico-química, Folclore, Fonética, Fotografia, Futebol, Genética, Geologia, Geometria, Gramática, História, Histologia, Informática, Jornalismo, Jurídico, Linguística, Literatura, Lógica, Linguagem marítima, Matemática, Mecânica, Medicina, Meteorologia (erroneamente grafada "Metereologia"), Linguagem militar, Mineralogia, Mitologia, Música, Linguagem náutica, Odontologia, Ortopedia, Parapsicologia, Patologia, Política, Psicologia, Psicanálise, Psicopatologia, Psiquiatria, Publicidade, Química, Religião, Retórica, Semiótica, Sociologia, Teologia, Tipologia, Veterinária e Zoologia.

Embora a abreviatura do domínio "Mitologia" seja prevista na lista do dicionário, constatou-se a ausência de rubrica em vários verbetes pesquisados: MUSA mu-sa Sm 1 na mitologia grega, cada uma das nove divindades que inspiravam e presidiam as artes $\mathbf{2}$ mulher inspiradora; mulher bonita, querida de todos: A Miss Brasil passou a ser a musa dos brasileiros e dos turistas estrangeiros. CICLOPE ci-clo-pe Sm na mitologia grega, gigante com um só olho no meio da testa.

4.3. Os verbetes apresentam:

a) categoria gramatical? Sim, conforme explicitado na Introdução: 
Todas as entradas são rotuladas pela classe de palavra a que pertencem. Os substantivos (S) são marcados pelo gênero quando é o caso (ex: menino $\mathbf{S m}$; casa $\mathbf{S f}$; clima $\mathbf{S m}$; crente, mártir S). Para o substantivo ainda são marcadas as subclasses concreto/abstrato, quando em oposição na mesma palavra, como em cachorrada que, como concreto, significa ' conjunto de cachorros, matilha' [a cachorrada ladrava sem parar] e, como abstrato, 'ação de má, canalhice' [Puxa, que cachorrada você fez comigo!]... Os verbetes referentes a verbos são subdivididos de acordo com a transitividade: Vt (transitivo) e Vi (intransitivo). A complementação dos Vt é marcada pela preposição que introduz os complementos. Assim, o chamado objeto direto não é anotado e, por isso, se coloca entre as primeiras acepções do verbo. Quando o verbo constrói com dois complementos, a notação é (...+Prep)... As subclasses verbais retidas serão: pronominal [Pron], impessoal [Imp], unipessoal [Unip], de ligação [Vlig] e auxiliar [Aux]... Os adjetivos que comportam complementação têm a preposição específica anotada entre parênteses: obediente $(+\mathrm{a})$, confiante $(+\mathrm{em})$, dependente $(+\mathrm{de}) \ldots$ As palavras gramaticais são tratadas de um modo especial porque é por meio delas que se percebe a orientação gramatical deste dicionário. Com exceção das preposições, dos advérbios e das interjeições, todas tiveram anotadas as suas subclasses: os artigos são definidos e indefinidos; os numerais são cardinais, ordinais, multiplicativos e fracionários; os pronomes são pessoais, de tratamento, demonstrativos, possessivos, relativos, interrogativos e indefinidos, as conjunções são coordenativas e subordinativas. As primeiras agrupam-se em aditivas, alternativas, adversativas, conclusivas e explicativas e as segundas, em causais, comparativas, concessivas, condicionais, conformativas, consecutivas, finais, integrantes, proporcionais e temporais. As interjeições foram registradas pelo que expressam na situação de discurso. (BORBA, 2004, p. VIII).

A informação gramatical aparece logo após a separação silábica, em negrito

b) gênero? Sim, é informado na Introdução, que

Os substantivos (S) são marcados pelo gênero quando é o caso [ex: menino $\mathbf{S m}$; casa Sf; clima Sm; crente, mártir S]... As palavras de gênero oscilante entram pela freqüência da forma: anota-se apenas $\mathbf{S}$, quando a diferença não é expressiva, e tanto faz usar um gênero ou outro [Cf personagem]. Quando a diferença de frequência é expressiva [70\%], anota-se o gênero preferido no registro escrito[...] (BORBA, 2004, p. VIII).

Os exemplos disso são: ACLIMAÇÃ̃O a-cli-ma-ção $\mathbf{S f}$ aclimatação: Os eucaliptos têm facilidade de aclimação. ACME ac-me Sm ponto culminante; clímax; auge: a doença atingira seu acme. A revolta chegara ao acme. - Do Gr akmê "ponta, ponto culminante".

c) sinonímia? Sim. A sinonímia é amplamente empregada e quase sempre como recurso adicional, auxiliando a explicitação dos sentidos dos verbetes: AFÁVEL a-fá-vel Adj 1 delicado; cortês; agradável: O pai era durão, mas a mãe, afável. 2 que traduz delicadeza ou benevolência: Tinha sempre para as pessoas um olhar afável. $\bullet$ Ant ríspido. CONTUDO contu-do Adv Expressa 1 contraste entretanto; no entanto: A Constituição de 1988, em diversos artigos, exige a regulamentação do conjunto de atividades do setor energético. Até agora, contudo, são esparsas e isoladas as iniciativas neste sentido. 2 restrição ou ressalva $\sim$ porém, todavia: $O$ pai que ama o filho não lhe deve poupar a vara. Castigá-lo severamente, se for o caso; contudo, sempre confiando no Senhor. 3 contraposição não obstante; todavia: Abelhas, formigas, aranhas são marcas da pequenez do homem na imensidão universal e, contudo, signos de seu poder para dominá-la. 4 oposição entretanto; todavia: Paquita tratava-o por diminutivos carinhosos. Exercia, contudo, sobre Olavo, uma tirania sem trégua. Ressalva: algumas vezes a definição é constituída apenas por sinonímias, em sequência e separadas por ponto-e-vírgula: ARRIÇADO ar-ri-ça-do Adj eriçado; irritado: Hermínia, arriçada, deu de ombros e saiu da sala. ARRIOSCA ar-ri-os-ca Sf (Lus Coloq) enrascada, cilada, sinuca.

d) variante(s) da entrada? Sim. A obra inclui variantes gráficas: 
ABDOME/ABDÔMEN ab-do-me/ab-dô-men Sm ventre; barriga. 0 A primeira forma é muito usada em LR; a segunda predomina em LJ. Ambas são registradas pelo VOLP. ACETILENO/ACETILENE a-ce-ti-le-no/a-ce-ti-le-ne $\mathbf{S m}$ hidrocarboneto gasoso à temperatura ambiente, incolor, que se emprega na iluminação. ACLIMATAR/ACLIMAR acli-ma-tar/a-cli-mar Vt 1 habituar a um clima: Trouxemos os leões quatro meses antes de o filme começar, para aclimatá-los...

e) variante(s) da definição? $\mathrm{Na}$ obra, preponderam as definições de caráter analítico: ALFABETO al-fa-be-to $\mathbf{S m} \mathbf{1}$ conjunto das letras usadas na grafia de uma língua 2 conjunto de sinais para transcrição fonética: $O$ braile é um alfabeto para cegos. ALGONQUIANO al-gonqui-a-no Adj de ou relativo a um período zoológico situado entre o arqueano e o paleozóico, e correspondente a um intervalo de tempo geológico de 2.500 a 570 milhões de anos; proterozóico. Muitas definições apresentam informações enciclopédicas complementares precedidas por uma marca especial: ABAFADOR a-ba-fa-dor Sm 1 pedal do piano que abafa o som 2 dispositivo que comprime o ar: $O$ abafador do escapamento do carro estava perfurado. Adj 3 que sufoca, sufocante: $O$ calor do outono é abafador. O Era o membro de uma seita cristã que abreviava a vida dos moribundos, depois de confessados e comungados, abafando-os com uma almofada.

As definições descritivas aparecem na obra quando o tipo analítico é insuficiente para a explicitação do sentido: LÁPIS lá-pis Sm estilete de grafite ou outro material colorido equivalente, envolvido em madeira, para escrever ou desenhar. BUSCA-PÉ bus-ca-pé Sm fogo de artifício preso a uma pequena haste de madeira, que sai ziguezagueando rente ao chão e termina em estouro: Compraram rojões e busca-pés para as festas juninas.

A obra emprega as definições metalinguísticas predominantemente nas conjunções, interjeições etc (palavras lexicais): ARRE ar-re Interj 1 expressa contrariedade: Que lamentável engano! Arre! $\mathbf{2}$ expressa alívio: Ainda bem que esta música barulhenta terminou. Arre! PORQUE por-que Conj [Subordinativa. Causal] $\mathbf{1}$ introduz uma oração que apresenta a causa do que se expressa na oração anterior, ou seja, a condição suficiente para que seu conteúdo seja verdadeiro: $O$ inimigo atacou o forte e só não o destruiu porque não se impôs sobre os seus canhões. Não gosto de leite. Só bebo porque vocês me obrigam. - precedido de ser compõe o segundo termo da correlação de causa iniciada por se: Se alguém aceita algum tipo de alimento na rua, é porque não tem nada para comer em casa. [Coordenativa. Explicativa] 2 apresenta a razão ou o motivo do que se constatou na oração anterior $\sim$ pois: Perfeitamente sincera sei que não fui, porque de há muito sabia do namoro de Hélio. Peço que não mande o dinheiro pelo correio, porque da outra vez nem chegou a carta. f) critérios para distinguir homonímia de polissemia? Quais? Sim. Consoante Introdução,

os homônimos homógrafos estão em entradas independentes enumeradas [manga ${ }_{1}$ e manga $_{2}$; para os homônimos ${ }^{3}$ homófonos, que têm a mesma pronúncia, mas grafia diferente [era/hera; caça/cassa] chama-se a atenção depois de $\mathbf{0}$, o mesmo acontecendo com os antônimos, quando são itens lexicais de bases diferentes [céu/inferno; alto/baixo; bom/mau; entrar/sair] e os parônimos [descrição/discrição]. (BORBA, 2004, p. VIII).

Na nota de rodapé, fica definido o critério que separa a homonímia da polissemia: "3 entenda-se por homônimos aqueles itens que têm o mesmo corpo fonético e sentidos diferentes, ou seja, não tenham nenhum traço semântico em comum independentemente de serem resultado de convergência fônica ou de algum outro expediente de nominação. Cf cardeal ${ }_{1}$, $\operatorname{cardeal}_{2}$ e cardeal $_{3}$." Portanto, na sistematização do dicionário, essa distinção é marcada por entradas distintas para os casos de homonímia, determinadas pela ausência de traço semântico comum dos vocábulos. As polissemias são destacadas como acepções distintas em cada verbete.

Homonímia: GALA 1 ga-la (Fr) Sf [Co] 1 traje próprio para ocasiões solenes: No desfile houve 
uma parte reservada só para gala. [Ab] 2 solenidade; festa grandiosa: $O$ embaixador liderou uma gala beneficente. 3 pompa; luxo: Os rapazes compareceram em trajes de gala. 4 honraria: Luciano já sonhava com as galas do cargo.

GALA $_{2}$ ga-la Sf 1 mancha germinativa do ovo 2 sêmen; esperma.

Polissemia: DENTE den-te Sm 1 cada uma das peças duras e esbranquiçadas implantadas sobre as bordas dos maxilares do homem e de certos animais e que servem para morder e mastigar 2 peça artificial colocada para substituir um dente original: Precisei implantar dois dentes. 3 ponta fina de ferramentas ou máquinas: os dentes do serrote $\mathbf{4}$ saliência ou borda de órgãos vegetais: os dentes das folhas $\mathbf{5}$ componente da cabeça ou bulbo do alho: dente de alho.

g) emprego de marcas de uso? Como se classificam? Empregam-se marcas de uso dos vocábulos. Conforme a lista na seção "Símbolos e Abreviaturas" classificam-se como: Arc. Arcaísmo; Ch. Chulo - BABACA ba-ba-ca Sf $(C h)$ vulva; Coloq. Coloquial - BAMBAMBÃ bam-bam-bã $\mathbf{S}$ (Coloq) pessoa muito bem preparada numa atividade; bamba (2): William é o bambambã dos calçados; Deprec. Depreciativo - BUGRADA bu-gra-da Sf (Deprec) grupo de bugres: A bugrada enfrentou os invasores com emboscada;

Gír. Gíria; Fam. Familiar; Folc. Folclore; Joc. Jocoso; Obsol. Obsoleto; Pej. Pejorativo; Pop. Popular - BICHA LOUCA bi-cha lou-ca Sm (Coloq Pop) homossexual masculino; bichana; Poét. Poético; Reg. Regionalismo - BOLICHO bo-li-cho Sm (Reg: RS) boliche (2).

h) indicação de área ou subárea de especialidade? Sim. As indicações são feitas logo após a informação da classe gramatical, entre parênteses, de acordo com a lista de abreviaturas. CALCEDÔNIA cal-ce-dô-ni-a Sf (Miner) variedade de sílica translúcida. CEFALORIDINA ce-fa-lo-ri-di-na Sf (Bioquím) antibiótico de ação semelhante à da penicilina, sintetizado a partir da cefalosporina.

i) contexto? (exemplo ou abonação?) Os exemplos são adequados, ajudando na explicitação das definições. São apresentados com regularidade, em itálico, após a acepção, precedido por dois pontos. Borba (2004, p. X) informa que "para patentear ou esclarecer melhor as acepções, utilizou-se um sistema de contextualização constituído por frases e expressões extraídas de textos reais do corpus, com adaptações ou condensações para melhor cumprir objetivos."

j) equivalente(s)? Não há equivalentes de línguas estrangeiras.

k) formação da palavra? Não há informações sobre as estruturas mórficas das lexias.

l) indicação de pronúncia? Indica-se a pronúncia de todos os empréstimos com grafia não aportuguesada, de forma aparentemente consistente e apropriada. É informado na Introdução, página X que "marcam-se entre colchetes as diversas pronúncias do $\mathrm{x}$ - exceto sua realização com o som de [š]e de [z] - como em tóxico [ks], sintaxe [s], e as oposições fonológicas do tipo corte /ô/ corte /ó/, esse /ê/ esse /é/. Também se marcaram os timbres ê, é, ô, ó de casos oscilantes, que podem suscitar dúvidas, como em descarrego [ê], incesto [é], alcova [ô], toro [ó]." BESTA 1 bes-ta [ê] Sf $\mathbf{1}$ quadrúpede de grande porte, em geral doméstico: $O$ transporte de carga era feito em bestas. 2 mula: Soltou a besta no pasto. 3 qualquer animal irracional: Certos motoqueiros são piores do que bestas selvagens. 4 pessoa bruta e estúpida: Nem de longe quero me encontrar com aquela besta. Adj 5 tolo; bobo [...]. BESTA $\mathbf{B}_{3}$ bes-ta [é] antiga arma que consiste num arco cujas extremidades são ligadas por uma corda que se retesa para disparar setas curtas. Para os chamados plurais metafônicos, informa-se a abertura da vogal $/ \mathrm{o} /$. SOCORRO so-cor-ro Sm 1 atendimento que se dá a uma pessoa acidentada ou acometida de mal súbito $[\ldots]$ ○ Pl soc[ó]rros.

m) origem e etimologia? Sim. Pela lista contida na seção "Símbolos $\boldsymbol{e}$ Abreviaturas", existem as seguintes indicações sobre a origem das palavras: Africano, Alemão, Árabe, Assírio, Catalão, Céltico, Chinês, Coreano, Dravídico, Escandinavo, Espanhol, Espanhol Platino, Esquimó, Finlandês, Francês, Frâncico, Germânico, Gótico, Grego, Havaiano, Hebraico, Híndi, Hispano-americano, Holandês, Húngaro, Inglês, Italiano, Japonês, Javanês, Latim, Lunfardo, Lusitanismo, Malaio, Malaiala, Linguagem marítima, Linguagem militar, Linguagem náutica, 
Polonês, Provençal, Quichua, Russo, Sânscrito, Tâmil, Tibetano. AÇOITE a-çoi-te (Ár) Sm [Co] 1 chicote [Ab] 2 golpe com esse objeto: Aos açoites se seguir a expulsão. 3 flagelo; castigo: Ninguém agüenta mais o açoite de tanta miséria. CHIQUE chi-que (Fr) Adj 1 elegante no trajar: Ela sempre foi uma mulher chique. $\mathbf{2}$ de bom gosto; elegante: uma roupa chique $\mathbf{3}$ valorizado pela sociedade: Até há pouco tempo era chique usar um celular. Sm $\mathbf{4}$ coisa ou fato valorizado: Na festa o brega convida o chique.DRAGA dra-ga (Ing) Sf aparelho para retirar areia ou entulho do fundo dos rios. Observação: Na Introdução, mais especificamente na página XI, é afirmado que "as palavras provenientes do tupi também são rotuladas e as provenientes das diversas línguas africanas se rotulam simplesmente como Afr (Africanismo)... As de base onomatopaica se rotulam como (Onomat) e as de origem controversa, duvidosa, desconhecida ou obscura recebem o rótulo (Or duv).”. ABACAXI a-ba-ca-xi (Tupi) Sm 1 infrutescência composta por bagas carnosas grudadas uma às outras formando uma polpa branca ou amarelada, aromática e suculenta, envolvida por uma casca grossa de sulcos simétricos e em forma cônica ou arredondada e curta, terminando por uma coroa espinhosa 2 abacaxizeiro: Feriu-se numa folha de abacaxi. 3. (Coloq) tudo o que é indesejável e perigoso; coisa complicada e trabalhosa: $O$ ministro afirmou estar assumindo um abacaxi muito grande. ABADÁ a-ba-dá (Afr) Sm uniforme, com camiseta ou camisão e short ou bermuda, facultativamente lenço ou boné, para participar de um bloco carnavalesco. ACIRRAR a-cir-rar (Or duv) Vt 1 aguçar; provocar: A propaganda acirra as vendas. A derrota do time acirrou a pancadaria. Vi [Pron] 2 tornar-se mais ativo; aguçar-se: Os conflitos se acirravam. Ressalva: embora existam as abreviaturas para "Frâncico" e "Tâmil", não foram encontradas essas entradas no dicionário.

Os autores não apresentam etimologia, mas, sim, origem, como em ABALROAR a-balro-ar Vt chocar-se com ; colidir com: O barco quase abalroa a lancha. $\mathbf{O}$ A partir do Esp balroa "âncora pequena amarrada por um cabo e usada para abordar outra embarcação". JÉRSEI jér-sei Sm tecido de malha muito fina: Experimentou apenas o vestidinho de jérsei. $\mathbf{0}$ Do Top Jersey, cidade inglesa onde esse tecido começou a ser fabricado.

n) divisão silábica? Sim. Ocorre sempre após a entrada, ao longo de toda a nomenclatura da obra, com destaque pela mudança de fonte: ABRUPTO ab-rup-to Adj 1 difícil de escalar; íngreme: montanhas abruptas 2 inesperado; súbito; repentino: A guerra teve um fim abrupto. ABSCISSA abs-cis-sa cada uma das coordenadas de um ponto sobre uma reta. 0 (i) Mais usado no pl (ii) O VOLP registra as duas grafias - abscissa e abcissa que, nos textos, são usadas equilibradamente.

o) nomenclatura científica? Não. O dicionário tem a preocupação de definir as entradas de forma clara e simples, evitando os nomes científicos e citações às famílias, espécies, ordens ou reinos. BESOURO be-sou-ro (Or Duv) Sm inseto de asas posteriores membranosas e as anteriores em forma de chifre, de tamanhos e cores variados. MONOCOTILEDÔNEA mo-noco-ti-le-dô-ne-a Adj 1 espécime da classe de plantas caracterizadas pelo embrião com apenas um cotilédone, geralmente sem crescimento secundário em espessura do caule e da raiz, folhas freqüentemente estreitas e com nervuras paralelas $[\mathrm{Pl}] \mathbf{2}$ essa classe.

p) remissivas úteis entre conceitos? Sim. Na lista contida na seção "Símbolos $\boldsymbol{e}$ Abreviaturas", as remissivas são indicadas pelas abreviaturas "Cp: Compare" e "Cf: Confira": CONCERTO con-cer-to (Ital) Sm [Co] 1 composição musical criada para ser executada por orquestra ou para fazer sobressair um instrumento: Ainda jovem, o autor compôs seu primeiro concerto para piano. 2 apresentação de um solista que toca um instrumento ou canta, acompanhado de orquestra ou piano; recital: Assistimos a um concerto do pianista Nélson Freire. 3 espetáculo em que são executados trechos ou composições musicais por um conjunto de instrumentos ou vozes: concerto de música clássica $[\mathrm{Ab}] \mathbf{4}$ conjunto harmonioso : $O$ concerto do universo prova a existência de Deus. O Cp conserto. GENÓTIPO ge-nó-ti-po Sm conjunto de genes de um indivíduo: A maciez da carne é influenciada pelo genótipo do animal. - Cp fenótipo.

q) fontes? Considerando que, para o autor, em sua outra obra Dicionário de usos do português do Brasil (2002), define abonação como "frase ou trecho de frase que serve para 
exemplificar uma acepção ou uma construção sintática dos dicionários", as fontes são apresentadas em uma seção anexa intitulada Corpus, páginas 1469 e 1470. Nessa seção, indicam-se todas as obras usadas para as abonações e os exemplos.

r) notas? Sim. Há várias informações gramaticais e etimológicas; indicações de variantes de baixa freqüência e equivalências mórficas, apresentações de homônimos homófonos; algumas menções sobre a forma original da palavra ou de suas relações com palavras estrangeiras, sempre destacadas pelo símbolo "O”: ABDOME/ABDÔMEN ab-do-me/ab-dômen Sm ventre; barriga. 0 A primeira forma é muito usada em LR; a segunda, predomina em LJ. Ambas são registradas pelo VOLP. ABSCISSA abs-cis-sa cada uma das coordenadas de um ponto sobre uma reta. - (i) Mais usado no $\mathrm{pl}$ (ii) O VOLP registra as duas grafias - abscissa e abcissa que, nos textos, são usadas equilibradamente. EXPERTO ex-per-to Adj (+em) especialista; perito; conhecedor: Os dois australianos eram expertos em surfe. 0 (i) Cp esperto (ii) A forma original inglesa expert é muito mais freqüente: Tinha a seu lado em expert em fotografia.

4.4. A definição é constituída de um enunciado de uma só frase? Sim. Geralmente seguida por um exemplo: ARROZ-DOCE ar-roz-do-ce $\mathbf{S m}$ prato preparado com arroz, água, leite e açúcar. ARRUMADEIRA ar-ru-ma-dei-ra Sf empregada incumbida da arrumação da casa. ARSENAL ar-se-nal (Ár) Sm [Co] 1 estabelecimento onde se fabricam e se armazenam armas e munições de guerra: As granadas tinham sido roubadas de um arsenal do Exército. 2 conjunto de armas, munições e apetrechos de guerra: $\mathrm{O}$ tratado prevê a redução dos arsenais nucleares. [Ab] $\mathbf{3}$ grande quantidade de: Nem o arsenal de efeitos especiais fez o filme aceitável pelo público.

4.5. A definição leva em conta o nível de discurso do usuário? A linguagem do dicionário é acessível, empregando vocabulário básico e freqüente, sem termos que dificultam a intelecção

\section{Sobre a edição e publicação}

5.1. Recomenda-se a edição e a publicação da obra? Sim. A proposta lexicográfica é consistente e a obra servirá de instrumento eficaz em sala de aula, tanto para o professor quanto para o aluno de nível médio e superior.

5.2. Quais serão os principais pontos de difusão da obra? Livrarias, bibliotecas e meios eletrônicos.

Título: Dicionário analógico da língua portuguesa: ideias afins ${ }^{5}$

Autor: Francisco Ferreira dos Santos Azevedo

Editora: Companhia Editora Nacional

Edição: $1^{\mathrm{a}}$

Data: 1950

Local de publicação: São Paulo

Volume(s): único

Epígrafe: Não há.

\section{Sobre o autor}

1.1. Trata-se de pessoa reconhecida na área de dicionarística ou de terminologia? O Professor Ferreira dos Santos tornou-se reconhecido na área de dicionarística por ter-se dedicado por muito tempo à organização de um dicionário brasileiro de ideias afins.

1.2. Fez parte de grupo de pesquisa da área de dicionarística ou de terminologia? Não é mencionado.

1.3 Qual a formação acadêmica do autor principal e dos participantes do grupo de pesquisa? Após ter cursado o Liceu de Goiás, Francisco Ferreira dos Santos Azevedo (1875- 1942) bacharelou-se em Agrimensura pela Escola de Minas de Ouro Preto. Em 1903, tornou-se

\footnotetext{
${ }^{5}$ Roteiro extraído da dissertação de mestrado "Confluência entre dicionário analógico e tesauro documentário como modelo de dicionário analógico" (2010), de Michelle Machado de Oliveira, orientada pela Professora Doutora Enilde Faulstich, na Linha de pesquisa Léxico e Terminologia.
} 
Professor do Liceu de Goiás, onde atuou na cadeira de geografia e matemática. O autor era conhecido como "Professor Ferreira".

1.4. Qual a profissão exercida na época da publicação da obra em análise? O Professor Ferreira faleceu antes da publicação da obra em análise, que foi lançada em 1950, 8 anos após a sua morte.

\section{Sobre a apresentação da obra pelo autor}

2.1. Há introdução na qual apareçam claramente:

a) os objetivos da obra? Na seção Nota explicativa, há a declaração de que a obra funciona como um auxiliar eficaz, de manuseio simples e de grande riqueza. Dada uma "ideia", a obra tem a finalidade de indicar as palavras que podem expressar essa ideia ou que com ela mantêm analogia. Foi para remover essas constantes dificuldades que o Professor Ferreira dos Santos dedicou inúmeros anos de sua vida ao trabalho paciente de pesquisar, colecionar e ordenar ideologicamente palavras e expressões da língua portuguesa. Como cada ideologia, cada emoção, cada necessidade, cada profissão requer o conhecimento de uma parte do vocabulário que não é a de uso comum, os dicionários são úteis, principalmente, os de ideias afins. Na apresentação da edição de 1974, há as informações de que a obra é o primeiro "thesaurus" da língua portuguesa, com vistas a proporcionar a correta manipulação da língua escrita, charadas, palavras cruzadas e é um instrumento fundamental para técnicos em documentação e computação.

b) o público para o qual o conteúdo se dirige? A obra é direcionada aos usuários da língua que, ao falarem ou ao escreverem, sentem falta de palavras precisas com que podem exprimir exatamente uma ideia ou com que podem evitar repetições desagradáveis.

c) as informações sobre como consultar o dicionário ou vocabulário? Na seção manuseio do dicionário, há orientações breves sobre como o consulente pode utilizar a obra.

d) referências à bibliografia de onde foi extraído o corpus? Na seção Nota explicativa, o revisor José Baptista da Luz, da Companhia Editora Nacional, relatou que Azevedo adotou a classificação das palavras segundo o sistema de Peter Mark Roget. Esse revisor declarou que a Companhia Editora Nacional terminara a parte final do dicionário - organização e disposição da matéria, o quadro sinóptico, além de terem acrescentado mais verbetes. Ao analisarmos o Vocabulário Analógico de Firmino Costa, identificamos que Azevedo copiou alguns lexemas e definições desse vocabulário, mas fez pequenas adaptações. No dicionário de Azevedo (1950), no verbete cores e sinais de cavalos, a maioria dos lexemas e das definições são iguais ou bem similares aos da obra de Costa (1936).

2.2. Há bibliografia de consulta justificada pelo autor? Apesar de não haver esclarecimento do autor com relação à bibliografia, o revisor José Baptista da Luz mencionou que o Professor Ferreira "adotou a classificação das palavras segundo o sistema de Peter Mark Roget por ser o método mais racional e o que mais apresenta facilidade na expressão de ideias."

\section{Sobre a apresentação material da obra}

3.1. Há prefácio redigido por personalidade reconhecida na área de dicionarística? Científica, técnica? Não há um prefácio, mas, sim, a seção intitulada nota explicativa, redigida pelo revisor José Baptista da Luz da Companhia Editora Nacional.

3.2. A família tipográfica empregada é adequada à faixa etária do usuário? O tamanho da fonte, o espaçamento entre linhas são elementos que facilitam a leitura do dicionário. No entanto, como os verbetes são compostos, geralmente, por enormes listas de palavras, o autor deveria ter estabelecido critérios para agrupar os lexemas de forma mais organizada.

3.3. As ilustrações, se houver, estão adequadas à microestrutura informacional? Não há ilustrações.

3.4. A utilização de negrito, de itálico e de outros recursos gráficos está de acordo com o equilíbrio visual da obra? Sim. Na primeira parte, que possui o dicionário analógico, as palavras-entrada e seus respectivos números classificatórios são destacados em negritos, as frases e os lexemas estrangeiros, em itálico. Há também outros lexemas destacados em itálico, 
mas não é compreensível o critério, tendo em vista que o autor não os especificou. Na segunda parte, as palavras-entrada são indicadas em negrito.

3.5. Os verbetes são apresentados em ordem alfabética? Em ordem sistemática? Os verbetes são apresentados em ordem sistemática, em conformidade com o número classificatório. A obra é constituída por: classificação das palavras, quadro sinópticos de categorias, primeira parte, que é o dicionário analógico, e índice remissivo. A classificação de palavras possui 6 categorias, subdivididas em 24 seções, numeradas de 1 a 1.000. O quadro sinóptico de categorias é formado pelo detalhamento da divisão feita na classificação de palavras, de modo que apresenta as 6 categorias subdivididas em 1.000 subcategorias acompanhadas da numeração classificatória. A primeira parte da obra contém, dispostos em colunas, os lexemas, que expressam as diferentes acepções, variantes e matizes de uma mesma ideia. Cada subcategoria do quadro sinóptico é a palavra-entrada de um verbete e possui um número classificatório correspondente. Nos verbetes, os lexemas estão separados por categoria gramatical. O índice remissivo indica o número correspondente a cada grupo de palavras que expressam uma ideia ou as relacionadas a esta.

3.6. A obra contempla uma só língua? Mais de uma? A obra é um dicionário monolíngue de língua portuguesa.

3.7. O formato do dicionário ou vocabulário permite manuseio prático e fácil? O dicionário é de tamanho médio, não muito grosso, permite o fácil manuseio.

3.8. A obra está editada em suporte informatizado? Não.

3.9. A qualidade do acabamento garante a sua durabilidade? A encadernação é de boa qualidade. $\mathrm{O}$ revestimento do dicionário é de papelão grosso.

3.10. O sistema de abreviações e de símbolos aparece corretamente no corpo do texto? Há uma breve lista de abreviaturas. Percebemos que não consta o que significa (poét.) na lista de abreviaturas e nem $\mathrm{V}$.

3.11. A obra possui ampla divulgação? A primeira edição foi esgotada, a segunda e a terceira edição foram lançadas em Brasília. Aquela, em 1974, pela editora Coordenada e esta, em 1983, pela Thesaurus e também estão esgotadas.

4. Sobre o conteúdo

4.1. As entradas cobrem de maneira exaustiva a língua oral e escrita, inclusive neologismos, palavras derivadas etc? Não. Apenas mil palavras-entrada compõem a obra, as quais são apresentadas no quadro sinóptico de categorias. Com base nessa forma de organizar os lexemas, o consulente tem dificuldade de encontrar lemas da língua oral e escrita.

4.2. Há entradas que se referem a áreas de especialidade? Sim, há entradas da área de especialidade, mas não configuram a área a que se referem de modo completo.

4.3. Os verbetes apresentam:

a) categoria gramatical?As categorias gramaticais adjetivos, verbos, advérbios e interjeições são indicadas por meio de suas respectivas abreviaturas marcadas em negrito e em itálico. Apesar de os verbetes começarem com os substantivos, não têm marcação para indicar esta classe gramatical.

b) gênero? Não.

c) sinonímia? Sim. Nos agrupamentos analógicos presentes na parte analógica, após as palavras-entrada, são apresentados os sinônimos.

d) variante(s) da entrada? Sim. Quando há variantes das entradas, são indicadas entre parênteses, antes das palavras-entrada, assim como ocorre nas entradas de numerações classificatórias 368 e 369, visto que a variante da entrada Zoologia é "Ciência dos animais" e a variante da entrada Botânica, "Ciência das plantas", entre parênteses (cf. figura 36 - 5.3. Ilustração da obra, p. 140)

e) variante (s) da definição? Não.

f) critérios para distinguir homonímia de polissemia? Quais? Como a obra apresenta agrupamentos analógicos, não há critérios para distinguir homonímia e polissemia. 
g) marcas de uso? Como se classificam? Apesar de não haver explicações nas páginas introdutória da obra referentes às marcas de uso, notamos que são indicadas por abreviaturas entre parênteses, tais como: (bras.), (pop.), (ant.), (reg.), (poét.), (desus.).

h) indicação de área ou subárea de especialidade? Não.

i) contexto? (exemplo ou abonação?) Não.

j) equivalente(s)? É um dicionário monolíngue, por isso não tem equivalente.

k) formação da palavra? Não.

l) indicação de pronúncia?Não.

m) origem e etimologia? Não.

n) divisão silábica? Não.

o) nomenclatura científica? A obra não apresenta.

p) remissivas úteis entre conceitos? As remissivas são indicadas pelos números classificatórios, pelos lexemas relacionados à palavra-entrada e pela abreviatura $\mathrm{V}$. que remete a outro lexema. No interior dos verbetes, geralmente, as remissões aos adjetivos são feitas nos lexemas da classe gramatical advérbio, as quais são indicadas da seguinte forma "\& adj.". No entanto, esse tipo de remissiva não é coerente para os consulentes, tornando-se, nesse caso, desnecessária.

q) fontes? Não.

r) notas? Não.

4.4. A definição é constituída de um enunciado de uma só frase? Não há definições nesta obra. 4.5. A definição leva em conta o nível de discurso do usuário? Não há definições nesta obra.

\section{Sobre a edição e publicação}

5.1. Recomenda-se a edição e a publicação da obra? É necessário reconhecermos que o autor venceu uma série de dificuldades, tendo em vista que, em Goiás, na época em que a obra foi elaborada, não havia elementos informativos suficientes, faltavam fontes de consulta, mas, mesmo com essas limitações, conseguiu produzir uma obra que tem seu lugar marcado dentro da literatura nacional. Apesar de haver falhas na obra, não podemos desprestigiá-la, pois serve como um difusor da cultura brasileira da época, além de possuir uma grande recolha de palavras relacionadas criadas após vinte anos de trabalho, que podem ser úteis à elaboração de outras obras lexicográficas.

5.2. Quais serão os principais pontos de difusão da obra? Como o autor é goiano, a obra é bastante conhecida em Goiás. Além disso, foi difundida em todo Brasil e pode ser facilmente encontrada nas bibliotecas nacionais e nos sebos. No jornal opção, edição nº 1592 de 2006, há o registro da declaração do músico e escritor Chico Buarque de Holanda, afirmando que o dicionário do Professor Ferreira é seu livro de estimação, o qual é uma herança do pai. Isto significa que a obra-prima do professor goiano também era utilizada pelo historiador e ensaísta Sérgio Buarque de Holanda, autor do clássico Raízes do Brasil e pai de compositor. Para muitos estudiosos, o Dicionário Analógico é considerado o mais importante livro escrito por um goiano.

\section{CONCLUSÃO}

Neste trabalho, apresentamos somente uma pequena amostra de muitos anos de estudo dos dicionários nacionais e estrangeiros, com vistas a que pesquisadores e estudantes de Lexicografia conheçam a forma como os dicionários foram concebidos e elaborados. Há um inventário já muito grande no Centro Lexterm da UnB, o que nos permite dizer que a macroestrutura e a microestrutura dos dicionários apresentam um conjunto de dados em comum, mas, não seguem um modelo estruturado que nos permita dizer se um é melhor ou pior que outro, na sua individualidade, mas, sim, no cotejo entre uns e outros. Há flutuações em função do usuário, do conjunto dados que compõem os campos, das informações dentro dos campos, 
questões que só podem ser vistas e reconhecidas se a análise do dicionário for feita de forma ordenada, com parâmetros de controle do que foi dito, de como foi dito e para quem foi dito. Depois de uma análise bem feita, é possível separar bons dicionários de outros e é possível recomendá-los de acordo com as necessidades dos usuários. Deixamos de analisar dicionários segundo uma tipologia, por causa do espaço dedicado a este artigo.

\section{BIBLIOGRAFIA}

AZEVEDO, Francisco Ferreira dos Santos. Dicionário analógico da língua portuguesa: ideias afins. São Paulo: Ed. Nacional, 1950.

BASTOS, José Timóteo da Silva. Diccionario etymologico, prosodico e orthographico da lingua portugueza. 2. ed. Lisboa : Parceria Antonio Maria Pereira, 1913. 1415 p.

BORBA, Francisco S. (Org.) Dicionário UNESP do português contemporâneo. São Paulo: Ed. da UNESP, 2004.

FAULSTICH, Enilde. Rede de remissivas em um glossário técnico. Cadernos do IL, Porto Alegre, n. 10, p. 91-98, 1993.

. Perspectivas da atividade terminológica no Brasil. Revista Internacional de Língua Portuguesa, Lisboa, n. 15, p. 37-52, 1996.

. Para gostar de ler um dicionário. In: RAMOS, Conceição de M. de A. (Org.). Pelos caminhos da dialetologia e da sociolinguística: entrelaçando saberes e vidas - homenagem a Socorro Aragão. São Luís, MA: EDUFMA, 2010. p. 166-185.

NASCENTES, Antenor. Dicionário etimológico da língua portuguesa. Rio de Janeiro: Francisco Alves, 1932.

OLIVEIRA, Michelle Machado de. Confluência entre dicionário analógico e tesauro documentário como modelo de dicionário analógico. 2010. 243 f. Dissertação. (Mestrado) Instituto de Letras, Programa de Pós-Graduação em Lingüística, Universidade de Brasília, 2010. OXFORD ADVANCED LEARNER'S DICTIONARY OF CURRENT ENGLISH. 4. ed. Oxford: Oxford University Press, 1989.

UNIVERSIDAD DE ALCALÁ DE HENARES. Departamento de Filologia. SEÑAS: diccionario para la enseñanza de la lengua española para brasileños. São Paulo: Martins Fontes, 2000. 